\title{
Effect of high carbon dioxide concentration on PAL activity and phenolic contents in ripening cherimoya fruit
}

\author{
Joston S. Assis ${ }^{1}$, Roberto Maldonado, Teresa Muñoz, María I. Escribano, \\ Carmen Merodio*
}

Departamento de Ciencia y Tecnología de Productos Vegetales, Instituto del Frío, Consejo Superior de Investigaciones Cientificas, Ciudad Universitaria, 28040-Madrid, Spain

Received 20 September 2000; accepted 9 February 2001

\begin{abstract}
Cherimoya fruit (Annona cherimola, Mill.) were kept at $20^{\circ} \mathrm{C}$ in air or in $20 \% \mathrm{CO}_{2}$ for 3 days and then transferred to air, to study the effect of a high $\mathrm{CO}_{2}$ treatment on phenolic metabolism and ripening-related changes. Total polyphenol levels remained constant while a rapid decline in lignin content was observed in cherimoyas stored in air. However, a sharp increase in PAL activity up to the second day at $20^{\circ} \mathrm{C}$ was observed. The maximum ethylene production was observed 2 days later. At the end of the $\mathrm{CO}_{2}$ treatment, ethylene production was inhibited and PAL activity was similar to that found in air-treated fruit. These data suggest that the increase in PAL activity at $20^{\circ} \mathrm{C}$ was not affected by high $\mathrm{CO}_{2}$ and does not relate to ethylene. The $\mathrm{CO}_{2}$ treatment inhibited flesh softening and maintained lignin at levels found in freshly harvested fruit. Exposure to $20 \% \mathrm{CO}_{2}$ also improved internal colour and increased the non-tannin polyphenol fraction, but prevented the decline in the tannin fraction otherwise observed upon ripening in air. We concluded that high $\mathrm{CO}_{2}$ treatment at $20^{\circ} \mathrm{C}$ did not enhance PAL activity and lignin deposition although treated fruits retained more lignin after transfer to air. The possible involvement of PAL activity in the supply of important metabolic compounds for early events of ripening will be discussed. (C) 2001 Elsevier Science B.V. All rights reserved.
\end{abstract}

Keywords: Cherimoya; Ambient temperature; High $\mathrm{CO}_{2}$ levels; Lignification; PAL; Polyphenols

\footnotetext{
* Corresponding author. Tel.: + 34-91-5445607; fax: + 3491-5493627.

E-mail address: merodio@if.csic.es (C. Merodio).

${ }^{1}$ Present address: Embrapa Semi-Arido, CP 23, CEP 56.300-000 Petrolina-Pernambuco-Brasil.
}

\section{Introduction}

The responses of fruit and vegetables to high $\mathrm{CO}_{2}$ levels vary considerably among cultivars and species, and include both undesirable and beneficial physiological and biochemical changes (Beaudry, 1999). Moreover, it is well known that the effect of $\mathrm{CO}_{2}$ depends on its dosage and environmental conditions such as temperature (Smith, 1992). 
High $\mathrm{CO}_{2}$ concentrations at $20^{\circ} \mathrm{C}$ delay or inhibit ripening and senescence in fruit and vegetables, but the mode of action is still not understood. Although most of the ripening-associated changes caused by high $\mathrm{CO}_{2}$ involve inhibition of ethylene production and action, high $\mathrm{CO}_{2}$ may regulate other development-dependent processes (Rothan et al., 1997). We observed that high $\mathrm{CO}_{2}$ treatment inhibited autocatalytic ethylene production in cherimoya fruit by increasing polyamine levels rather than by directly acting on the ethylene synthesis (Muñoz et al., 1999). Moreover, in this fruit, it is believed that ethylene is the coordinator rather than the trigger for the initiation of many ripening-related changes (Kosiyachinda and Young, 1975).

$\mathrm{CO}_{2}$ treatment also prevented fruit softening and modified the activity and content of cell wall degrading enzymes (Del Cura et al., 1996). However, the levels and activities of polymer degrading enzymes in cell walls are not always consistent with the rate of fruit softening. Furthermore, fruit texture can be modified by the presence of many sclereids in mesocarp tissues of some fruits, such as cherimoyas, which become highly lignified and hard (Schroeder, 1951). These cells contain substantial quantities of lignin, a hydrophobic polymer of $p$-hydroxycinnamyl, conferyl and sinapyl alcohols, some of which is bound to the polysaccharide of the cell wall. The density and extent of development of the sclerenchyma may be associated, to some extent, with the observed texture. As with lignin, tannins are widespread phenolic compounds with several functions, including the strengthening of cell walls. Tannins are also responsible for astringency in many fruits, affecting palatability and the nutritional value (Singleton, 1981). For these reasons, it is interesting to analyse their changes during ripening under different postharvest treatments.

High $\mathrm{CO}_{2}$ treatments promote changes in the composition of specific phenolic compounds and in the activities of enzymes of the complex biosynthetic pathway implicated in their accumulation (Mateos et al., 1993; Prusky et al., 1996). LPhenylalanine ammonia-lyase (PAL, EC 4.3.1.5.) is located at the first step in the pathway of phenylpropanoid biosynthesis and is a potential site for pathway regulation. PAL catalyses the deamination of L-phenylalanine, and the product, trans-cinnamate, is converted in plants to various phenylpropanoid compounds such as chlorogenic acid, lignin monomers, and flavonoids.

The objective of this investigation was to establish the changes in phenylpropanoid compounds (lignin, tannins, and non-tannin polyphenols) and PAL activity in ripening cherimoya fruit, and to evaluate the effect of high $\mathrm{CO}_{2}$ levels at $20^{\circ} \mathrm{C}$ on lignification and desirable ripening characteristics.

\section{Materials and methods}

\subsection{Plant material}

Cherimoya (Annona cherimola Mill. cv. Fino de Jete) fruit from early season (October) were harvested in Almuñecar (Granada) and transported overnight by road to our laboratory in Madrid where they were classified according to uniformity of colour, maturity, size and weight. Cherimoyas were divided into two lots of 25 fruits each and placed in separate respiration chambers $(201)$ in a continuous flow $\left(100 \mathrm{ml} \mathrm{min}^{-1}\right)$ of humidified air (air-treated) or a gas mixture containing 20\% $\mathrm{CO}_{2}+20 \% \quad \mathrm{O}_{2}+60 \% \quad \mathrm{~N}_{2} \quad\left(\mathrm{CO}_{2}\right.$-treated $)$ and stored at $20^{\circ} \mathrm{C}$. Two additional lots of 10 fruits each were placed under the same experimental conditions and used for measurement of ethylene production. After 3 days under $\mathrm{CO}_{2}$ treatment, the fruits were transferred to air for 2 additional days. Air-treated fruit were sampled after 1, 2, 3, 4 and 5 days of storage at $20^{\circ} \mathrm{C}$. Fruit treated with $\mathrm{CO}_{2}$ were sampled after treatment (3 days) and on the first and second day after transfer to air. Each sample consisted of three cherimoyas randomly collected, peeled and quick-frozen in liquid nitrogen and lyophylized or stored at $-80^{\circ} \mathrm{C}$.

\subsection{Colour, firmness and ethylene measurements}

The colour measurements were made with a HunterLab tristimulus colorimeter (model D25A9) calibrated with a white standard tile $(X=$ 82.51; $Y=84.53 ; Z=101.23)$. $L, a$ and $b$ values were assigned on the basis of the average of three 
representative fruits, with three readings taken (on the pedicellate area) for each fruit. Chroma $C=$ $\left(a^{2}+b^{2}\right)^{\frac{1}{2}}$ was calculated. The firmness of each fruit was measured using an Instron model 1140 texturometer fitted with an $8 \mathrm{~mm}$ diameter probe. The force required to insert the probe $8 \mathrm{~mm}$ into the flesh was measured without skin. Ethylene production was measured on 10 fruits, enclosed in an air-tight glass container continuously flushed with either air or the $\mathrm{CO}_{2}$-treatment mix at a flow rate of $100 \mathrm{ml} \mathrm{min}{ }^{-1}$. Aliquots of $1 \mathrm{ml}$ of effluent gas were injected into a gas chromatograph (Varian model 3700) equipped with a Porapak Q $(4 \mathrm{~m} \times 3.2 \mathrm{~mm})$ column and a flame ionisation detector with $\mathrm{He}$ as the carrier gas. Quantification was performed using an external standard and the results were expressed in $\mu$ l ethylene per $\mathrm{h}$ per $\mathrm{kg}$ of fresh weight.

\subsection{Phenolic compounds}

Total phenolic compounds were extracted from frozen and lyophylized mesocarp samples $(2.5 \mathrm{~g})$ four times with $25 \mathrm{ml} 1 \%(\mathrm{v} / \mathrm{v}) 11 \mathrm{~N} \mathrm{HCl}$ in methanol for $1 \mathrm{~h}$ each time under continuous stirring and centrifuged at $2000 \times g$ for $10 \mathrm{~min}$. The combined supernatant and final residue was used for analysis of polyphenols and lignins, respectively.

An aliquot of the total phenolic fraction $(15 \mathrm{ml})$ was dried and redissolved in methanol:ethanol:water $(1: 3.8: 0.2, \mathrm{v} / \mathrm{v} / \mathrm{v})$, centrifuged at $2000 \times g$, and loaded onto a $1.5 \times 20$ $\mathrm{cm}$ Sephadex LH-20 gel lipophilic filtration column (Sigma) saturated with 95\% (v/v) ethanol/ water. Non-tannins were first eluted using 95\% $(\mathrm{v} / \mathrm{v})$ ethanol/water with a flow rate of $3 \mathrm{ml}$ $\min ^{-1}$. Fractions of $3 \mathrm{ml}$ were collected and non-tannin elution was monitored following the absorbance at $280 \mathrm{~nm}$. Fractions containing nontannins were pooled, evaporated and resuspended in $10 \mathrm{ml} 1 \%(\mathrm{v} / \mathrm{v}) 11 \mathrm{~N} \mathrm{HCl}$ in methanol. The retained tannin fraction was eluted following the same procedure but using $50 \%(\mathrm{v} / \mathrm{v})$ acetone/water as eluent and monitoring the collected fractions at $400 \mathrm{~nm}$. Total, tannin and non-tannin polyphenol fractions were quantified using the Prussian blue method (Price and Butler, 1977), which gives less protein interference than other oxidation-reduction reactions such as with the Folin-Ciocalteu reagent. Results were expressed as $\mathrm{mg}$ gallic acid per $\mathrm{g}$ dry weight.

\subsection{Lignin content}

Lignin (Klason-lignin) content was determined gravimetrically after acid hydrolysis of the insoluble-alcohol residue under previously established conditions (Saura-Calixto et al., 1991). This residue was mixed with $12 \mathrm{M} \mathrm{H}_{2} \mathrm{SO}_{4}(1: 9$, w/v) and hydrolysed for $3 \mathrm{~h}$ at $20^{\circ} \mathrm{C}$ with stirring. The solution was then diluted with distilled water up to $1 \mathrm{M} \mathrm{H}_{2} \mathrm{SO}_{4}$, and heated for $2.5 \mathrm{~h}$ at $100^{\circ} \mathrm{C}$ with continuous shaking, cooled, vacuum filtered through an acid-treated $0.45 \mu \mathrm{m}$ Millipore HVLP filter, and rinsed with $100^{\circ} \mathrm{C}$ distilled water. The filter containing Klason-lignin was air-dried at $60^{\circ} \mathrm{C}$ overnight and weighed. Results were expressed as g lignin per $100 \mathrm{~g}$ dry weight. In order to avoid interference from proteins, Klanson lignin values were corrected for nitrogen impurity.

\subsection{Phenylalanine ammonia-lyase activity}

The procedure described by Cheng and Breen (1991), with some modifications, was used for extraction and assay of PAL activity from acetone powders. Frozen pulp (5 g) was ground with a pestle and mortar, placed on dry ice, homogenised with chilled $80 \%$ acetone $(1: 10 \mathrm{w} / \mathrm{v})$ and placed in a freezer for $15 \mathrm{~min}$. The homogenate was filtered and the pellet dried under vacuum (acetone powder). Protein extract was obtained by homogenising $0.5 \mathrm{~g}$ acetone powder in $5 \mathrm{ml} 0.1 \mathrm{M}$ sodium borate buffer, $\mathrm{pH} 8.8$, containing $5 \mathrm{mM} \beta$-mercaptoethanol, $2 \mathrm{mM}$ EDTA and 4\% (w/v) PVP at $4^{\circ} \mathrm{C}$. After $1 \mathrm{~h}$, the homogenate was centrifuged at $27000 \times g$ for $30 \mathrm{~min}$ at $4^{\circ} \mathrm{C}$. The reaction mixtures contained $0.5 \mathrm{ml}$ of $30 \mu \mathrm{M}$ L-phenylalanine, $30 \mathrm{mM}$ sodium borate buffer, $\mathrm{pH} 8.8$, and $1 \mathrm{ml}$ crude extract in a total volume of $3 \mathrm{ml}$. The substrate was added after 10 min of preincubation and the reaction was stopped with $0.1 \mathrm{ml} 6 \mathrm{~N}$ $\mathrm{HCl}$. PAL activity was determined by the production of cinnamate for $90 \mathrm{~min}$ at $30^{\circ} \mathrm{C}$ with continuous shaking, measured by the absorbance change 
at $290 \mathrm{~nm}$ (Zucker, 1965). Specific enzyme activity was defined as nmol cinnamic acid per $\mathrm{h}$ per $\mathrm{mg}$ of protein.

\subsection{Statistical analyses}

The data from at least three replicates were processed by one-way ANOVA using the least significant test (Statgraphics program, STSC, Rockville, Md.) to determine the level of significance at $P \leq 0.05$.
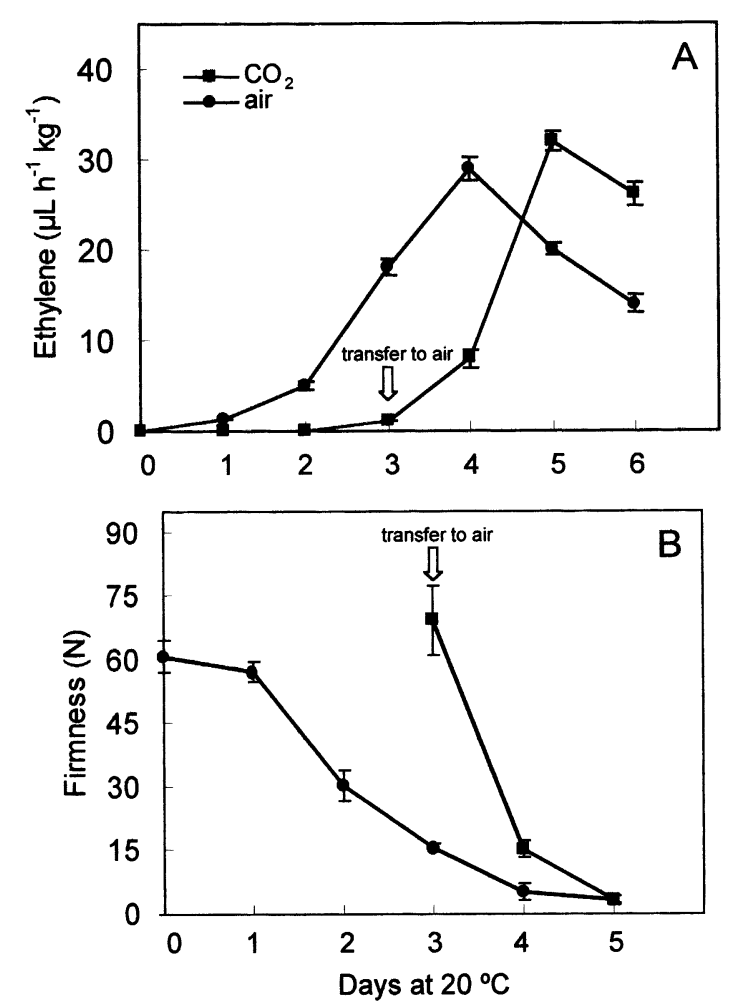

Fig. 1. Ethylene production (A) and flesh firmness (B) in air-treated cherimoyas during ripening, and in $20 \% \mathrm{CO}_{2}$ treated cherimoyas at the end of treatment ( 3 days) and after transfer to air for 1 and 2 additional days. For ethylene production data are means of two separate experiments $(n=$ $10)$. For flesh firmness data are means of two separate experiments $(n=6)$ and SE are shown by vertical bars.

\section{Results and discussion}

\subsection{Effect of high $\mathrm{CO}_{2}$ treatment on fruit ripening}

Cherimoya fruit exhibited a typical maximum in ethylene production after 4 days in air (Fig. 1A). At the end of $\mathrm{CO}_{2}$ treatment, cherimoyas had lower ethylene levels than those stored in air and similar to freshly harvested fruits (Fig. 1A). When $\mathrm{CO}_{2}$ was removed, the ethylene production rate increased, reaching a maximum 2 days later, comparable to that of the control fruit. Our previous work suggests that high $\mathrm{CO}_{2}$ treatment inhibits autocatalytic ethylene production by modulating the flux of $S$-adenosylmethionine through polyamine synthesis (Muñoz et al., 1999).

Air-treated fruit softened rapidly, reaching about $20 \mathrm{~N}$ after 3 days at room temperature (Fig. 1B). Thereafter, softening continued at a lower rate. High $\mathrm{CO}_{2}$ treatment maintained cherimoya flesh firmness. At the end of the treatment, firmness values were similar to those of freshly harvested fruit but decreased rapidly after transfer to air (Fig. 1B). A positive effect of high $\mathrm{CO}_{2}$ levels on retention of firmness has already been reported (Del Cura et al., 1996).

The colour of cherimoya mesocarp tissues (Table 1), ranges from a brilliant white to grey at later stages of ripening. The appearance of $\mathrm{CO}_{2}$ treated fruit was better than that of air-treated fruit due to the smaller changes in $L$ (lightness) and the enhancement of $b$ values during $\mathrm{CO}_{2}$ treatment. Moreover, the chroma values confirmed that at the end of treatment, $\mathrm{CO}_{2}$-treated cherimoyas were chromatically more yellow than air-treated fruit. Although $\mathrm{CO}_{2}$-treated cherimoyas were discoloured (yellowness) after transfer to air, this was less than in air-stored fruit. In the case of green tissues of cherimoya, Del Cura et al. (1996) reported that the beneficial effect of $20 \%$ $\mathrm{CO}_{2}$ on the retention of green colouring may be mediated by maintenance of chlorophyll and $\mathrm{RuBPC}$ ase protein content in $\mathrm{CO}_{2}$-treated tissues. In the case of mesocarp tissues (free of photosynthetic capacity), the effect of high $\mathrm{CO}_{2}$ in keeping cherimoya fruit more yellow could be due to a greater accumulation of secondary products of the 
Table 1

$L, b$ and chroma values in mesocarp tissues of air-treated and $20 \% \mathrm{CO}_{2}$-treated cherimoyas at the end of treatment (3 days) and after transfer to air for 1 and 2 additional days at $20^{\circ} \mathrm{C}$

\begin{tabular}{|c|c|c|c|c|c|c|c|}
\hline \multicolumn{2}{|c|}{ Storage time (days) } & \multicolumn{2}{|l|}{$L$} & \multicolumn{2}{|l|}{$b$} & \multicolumn{2}{|l|}{ Chroma } \\
\hline Air & $\mathrm{CO}_{2}$ & Air & $\mathrm{CO}_{2}$ & Air & $\mathrm{CO}_{2}$ & Air & $\mathrm{CO}_{2}$ \\
\hline 0 & 0 & $72.7 \pm 0.33^{a}$ & $72.7 \pm 0.33$ & $12.0 \pm 0.20$ & $12.0 \pm 0.20$ & $12.1 \pm 0.04$ & $12.1 \pm 0.04$ \\
\hline 3 & 3 & $63.1 \pm 0.31$ & $66.2 \pm 0.55$ & $12.9 \pm 0.06$ & $15.0 \pm 0.64$ & $13.1 \pm 0.02$ & $15.0 \pm 0.42$ \\
\hline 4 & $3+1$ & $60.1 \pm 0.37$ & $60.2 \pm 0.06$ & $13.5 \pm 0.11$ & $13.6 \pm 0.09$ & $13.8 \pm 0.05$ & $13.9 \pm 0.11$ \\
\hline
\end{tabular}

${ }^{\mathrm{a}}$ Means of two separate experiments $(n=6) \pm \mathrm{SE}$.

Table 2

Total polyphenols, tannin and non-tannin fractions in mesocarp tissues of air-treated and $20 \% \mathrm{CO}_{2}$-treated cherimoyas at the end of treatment ( 3 days), and after transfer to air for 1 and 2 additional days at $20^{\circ} \mathrm{C}^{\mathrm{a}}$

\begin{tabular}{|c|c|c|c|c|c|c|c|}
\hline \multicolumn{2}{|c|}{ Storage time (days) } & \multicolumn{2}{|c|}{ Total polyphenols (mg g $\left.{ }^{-1} \mathrm{DW}\right)$} & \multicolumn{2}{|c|}{ Tannin $\left(\mathrm{mg} \mathrm{g}^{-1} \mathrm{DW}\right)$} & \multicolumn{2}{|c|}{ Non-tannin $\left(\mathrm{mg} \mathrm{g}^{-1} \mathrm{DW}\right)$} \\
\hline Air & $\mathrm{CO}_{2}$ & Air & $\mathrm{CO}_{2}$ & Air & $\mathrm{CO}_{2}$ & Air & $\mathrm{CO}_{2}$ \\
\hline 0 & 0 & $5.70 \mathrm{a}$ & $5.70 \mathrm{a}$ & $2.44 \mathrm{a}$ & $2.44 \mathrm{a}$ & $3.24 \mathrm{a}$ & $3.24 \mathrm{a}$ \\
\hline 3 & 3 & $5.84 \mathrm{a}$ & $6.66 \mathrm{~b}$ & $2.11 \mathrm{~b}$ & $2.50 \mathrm{a}$ & $3.59 \mathrm{~b}$ & $3.94 \mathrm{~b}$ \\
\hline 4 & $3+1$ & $5.65 \mathrm{a}$ & $5.39 \mathrm{a}$ & $2.01 \mathrm{~b}$ & $2.07 \mathrm{~b}$ & $3.84 \mathrm{~b}$ & $3.97 \mathrm{~b}$ \\
\hline 5 & $3+2$ & $5.36 \mathrm{a}$ & $5.44 \mathrm{a}$ & $1.88 \mathrm{~b}$ & $1.97 \mathrm{~b}$ & $3.47 \mathrm{~b}$ & $3.76 \mathrm{~b}$ \\
\hline
\end{tabular}

${ }^{a}$ Means $(n=6)$ within columns with different letters denotes a statistically significant difference $($ LSD $=95 \%)$.

phenylpropanoid pathway (mainly non-tannins) caused by the treatment.

\subsection{Effect of high $\mathrm{CO}_{2}$ levels on phenolic compounds}

Total polyphenol content did not significantly change in cherimoya fruit during storage in air but an increase was observed at the end of $\mathrm{CO}_{2}$ treatment. When $\mathrm{CO}_{2}$ was removed, the levels decreased to those of the air-treated fruits (Table 2). The increase in total polyphenols in $\mathrm{CO}_{2}$-treated cherimoyas was due to the higher accumulation in the non-tannin fraction along with maintenance of the tannin fraction. As shown in Table 2, the tannin fraction decreased in ripened fruit. Our results suggest that in cherimoya fruit a tannin/non-tannin ratio (1:2) could be indicative of the ability for ripening. In bananas, it has been reported that, whereas the green pulp contains considerable levels of condensed tannins, ripe pulp appears to contain none (Jones, 1965). Although tannins are involved in the 'taste' factor of astringency, the relevance of tannins in ripening requires further research. The involvement of tannins in ripening may be associated with the ability of condensed tannins or polymers of proanthocyanidins to form complexes with proteins and other components (Hagerman and Butler, 1981).

\subsection{Effect of high $\mathrm{CO}_{2}$ levels on lignin content}

Lignin content declined up to the second day of ripening, at which time it was $51 \%$ less than the initial value (Fig. 2A), and then declined more slowly. cherimoyas have large masses of sclereids, highly lignified and extremely hard (Schroeder, 1951). Our results showed that the values of lignin at the end of $\mathrm{CO}_{2}$ treatment were significantly higher $(P \leq 0.05)$ than in air-treated fruit, although the values were similar to those of freshly harvested fruit. After transfer to air, lignin content decreased slightly in $\mathrm{CO}_{2}$-treated fruit but remained significantly higher than in the airtreated controls. These 
data indicate that high $\mathrm{CO}_{2}$ treatment promotes changes in lignin degradation. It is possible that cell walls maintaining more lignin deposits, can modulate the strength of cell-cell adhesion. An enhancement of cell-cell adhesion has been detected after $\mathrm{CO}_{2}$ treatment of strawberry fruit (Harker et al., 2000). Furthermore, in considering the insecticidal effects attributed to enriched $\mathrm{CO}_{2}$ treatment and the importance of phenylpropanoid compounds in general defence strategies, our data suggest that the maintenance of these compounds in $\mathrm{CO}_{2}$-treated fruit may be an advantage in pathogen defence.

\subsection{Effect of high $\mathrm{CO}_{2}$ levels on PAL activity}

PAL catalyses the first reaction in the general pathway of phenylpropanoid biosynthesis and is
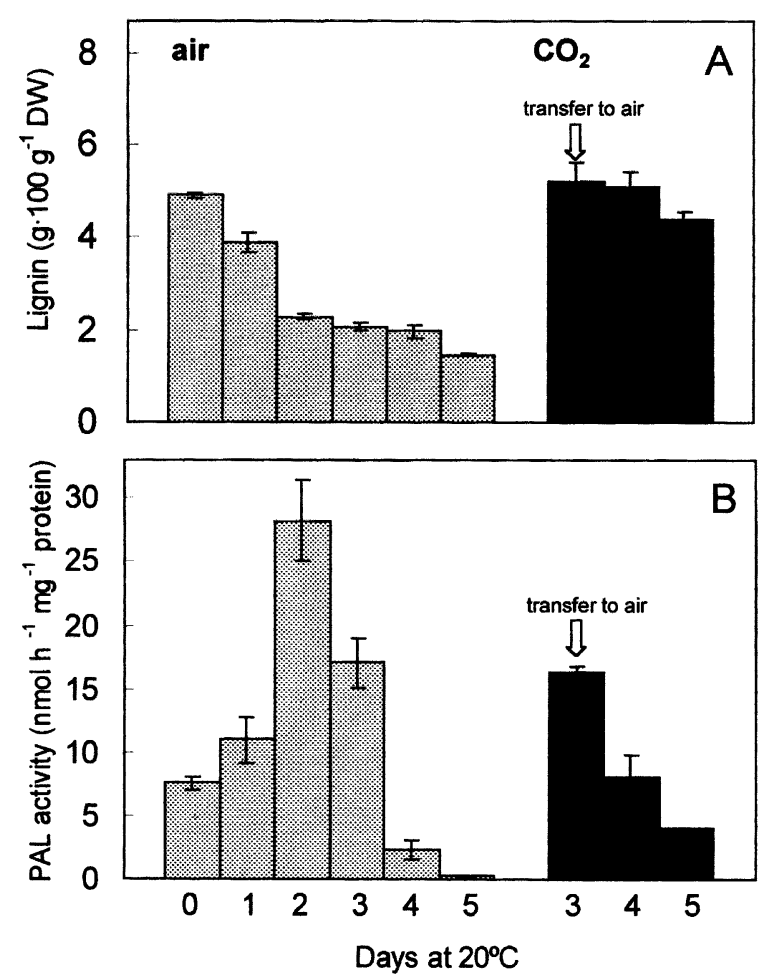

Fig. 2. Lignin content (A) and phenylalanine ammonia-lyase activity (B) in air-treated cherimoyas during ripening, and in $20 \% \mathrm{CO}_{2}$-treated cherimoyas at the end of treatment (3 days) and after transfer to air for 1 and 2 additional days. Data are means of two separate experiments $(n=6)$ and SE are shown by vertical bars. the first of the enzymes involved in lignin cell wall deposition. Our results confirmed that PAL activity increased from freshly harvested fruit to the second day, peaking before ethylene production and decreasing thereafter (Fig. 2B). PAL activity at the end of the $\mathrm{CO}_{2}$ treatment was higher than in freshly harvested fruit but similar to that of air-treated fruit after 3 days. It has been reported that PAL is transcriptionally induced in response to development and ripening (Given et al., 1988; Diallinas and Kanellis, 1994). However, activation of PAL has been observed in response to several kinds of stress including $\mathrm{CO}_{2}$ treatment (Ke and Salveit, 1989) and low temperature (Martínez-Téllez and Lafuente, 1997). Moreover, López-Galvez et al., (1996) reported that higher levels of PAL were induced by combining different kinds of stress (wounding plus ethylene), although the initial induction kinetics and the time to reach maximum PAL levels were similar. Our results confirmed that PAL activity increased in fruit stored in air at $20^{\circ} \mathrm{C}$, unmediated by ethylene, and that high $\mathrm{CO}_{2}$ treatment did not enhance such activity.

Our results suggest that an increase in PAL activity does not have a corresponding impact on the changes of the major product, lignin, or on the total polyphenols content. However, it is clear that some compounds released in the PALcatalysed reaction from the conversion of phenylalanine to cinnamate must be accumulating. It could be argued that the increase in PAL activity, the first enzyme of the phenylpropanoid pathway, early during storage in air, was to ensure an adequate supply of available nitrogen for further ripening metabolic processes. In this regard, a high level of nitrogenous compounds free or conjugated to phenolic compounds during the first days of cherimoya fruit ripening has been observed in previous studies (Escribano and Merodio, 1994; Escribano et al., 1996). Moreover, these compounds might be considered as a part of a whole suite of integrated responses triggered immediately after harvest and related to the low cytoplasm $\mathrm{pH}$ of this fruit as determined by ${ }^{31} \mathrm{P}$ NMR measurements (Muñoz et al., 2001). This possibility is now being investigated. 


\section{Acknowledgements}

This work was supported by a grant from Spain, CICYT (ALI99-0954-C03-01). Dr Joston S. de Assis was funded by Embrapa-Brasil.

\section{References}

Beaudry, R.M., 1999. Effect of $\mathrm{O}_{2}$ and $\mathrm{CO}_{2}$ partial pressure on selected phenomena affecting fruit and vegetable quality. Postharvest Biol. Technol. 15, 293-303.

Cheng, G.W., Breen, P.J., 1991. Activity of phenylalanine ammonia-lyase (PAL) and concentrations of anthocyanins and phenolics in developing strawberry fruit. J. Am. Soc. Hort. Sci. 116, 865-869.

Del Cura, B., Escribano, M.I., Zamorano, J.P., Merodio, C., 1996. High carbon dioxide delays postharvest changes in RuBPCase and polygalacturonase-related protein in cherimoya peel. J. Am. Soc. Hort. Sci. 121, 735-739.

Diallinas, G., Kanellis, A.K., 1994. A pheylalanine ammonialyase from melon fruit: cDNA cloning, sequence and expression in response to development and wounding. Plant Mol. Biol. 26, 473-479.

Escribano, M.I., Merodio, C., 1994. The relevance of polyamine levels in cherimoya (Annona cherimoya Mill.) fruit ripening. J. Plant Physiol. 144, 207-212.

Escribano, M.I., Aguado, P., Reguera, R.M., Merodio, C., 1996. Conjugated polyamines levels and putrescine synthesis in cherimoya fruit during storage at different temperatures. J. Plant Physiol. 147, 736-742.

Given, N.K., Venis, M.A., Grierson, D., 1988. Purification and properties of phenylalanine ammonia-lyase from strawberry fruit and its synthesis during ripening. J. Plant Physiol. 133, 31-37.

Hagerman, A.E., Butler, L.G., 1981. The specifity of proanthocyanidin-protein interactions. J. Biol. Chem. 259, 4494-4497.

Harker, F.R., Elgar, H.J., Watkins, C.B., Jackson, P.J., Hallett, I.C., 2000. Physical and mechanical changes in strawberry fruit after high carbon dioxide treatments. Postharvest Biol. Technol. 19, 139-146.

Jones, D.E., 1965. Banana tannin and its reaction with polyethylene glycols. Nature 206, 299-300.

Ke, D., Salveit, M.E. Jr., 1989. Carbon dioxide-induced brown stain development as related to phenolic metabolism in Iceberg lettuce. J. Am. Soc. Hort. Sci. 114, 789-794.

Kosiyachinda, S., Young, R.E., 1975. Ethylene production in relation to the initiation of respiratory climacteric in fruit. Plant Cell Physiol. 16, 595-602.
López-Galvez, G., Saltveit, M., Cantwell, M., 1996. Woundinduced phenylalanine ammonia-lyase activity: factors affecting its induction and correlation with the quality of minimally processed lettuces. Postharvest Biol.Technol. 9, $223-233$.

Martínez-Téllez, M.A., Lafuente, M.T., 1997. Effect of high temperature conditioning on ethylene, phenylalanine ammonia-lyase, peroxidase and polyphenol oxidase activities in flavedo of chilled 'Fortune' mandarin fruit. J. Plant Physiol. 150, 674-678.

Mateos, M., Dangyang, K., Cantwell, M., Kader, A.A., 1993. Phenolic metabolism and ethanolic fermentation of intact and cut lettuce exposed to $\mathrm{CO}_{2}$-enriched atmospheres. Postharvest Biol. Technol. 3, 225-233.

Muñoz, M.T., Aguado, P., Ortega, N., Escribano, M.I., Merodio, C., 1999. Regulation of ethylene and polyamine synthesis by elevated carbon dioxide in cheromoya fruit stored at ripening and chilling temperatures. Aust. J. Plant Physiol. 26, 201-209.

Muñoz, M.T., Ruiz-Cabello, J., Molina-García, A.D., Escribano, M.I., Merodio, C., 2001. Chilling temperature storage changes the inorganic phosphate pool distribution in cherimoya (Annona cherimola Mill.) fruit. J. Amer. Soc. Hort. Sci. 126, 122-127.

Price, M.L., Butler, L.G., 1977. Rapid visual estimation an spectrophotometric determination of tanin content of sorghum grain. J. Agric. Food Chem. 25, 1268-1273.

Prusky, D., Hamdan, H., Ardi, R., Keen, N.T., 1996. Induction of biosynthesis of epicatechin in avocado suspension cells treated with an enriched $\mathrm{CO}_{2}$ atmosphere. Physiol. Mol. Plant Pathol. 48, 171-178.

Rothan, C., Duret, S., Chevalier, C., Raymond, P., 1997. Suppression of ripening-associated gene expression in tomato fruit subjected to a high $\mathrm{CO}_{2}$ concentration. Plant Physiol. 114, 255-263.

Schroeder, C.A., 1951. Fruit morphology and anatomy of the cherimoya. Bot. Gazette 6, 436-446.

Saura-Calixto, F., Goñi, I., Mañas, E., Abia, R., 1991. Klanson lignin, condensed tannins and resistant protein as dietary fibre constituents: determination in grape pomaces. Food Chem. 39, 299-309.

Smith, R.B., 1992. Controlled atmosphere storage of 'Redcoat' strawberry fruit 1992. J. Am. Soc. Hort. Sci. 117, 260-264.

Singleton, V.L., 1981. Naturally occurring food toxicants: phenolic substances of plant foods. Adv. Food Res. 27, $149-242$.

Zucker, M., 1965. Induction of phenylalanine deaminase by light and its relation to chlorogenic acid synthesis in potato tuber tissue. Plant Physiol. 40, 779-784. 